\title{
WATER BALANCE AND BODY FLUIDS DISTRIBUTION OF BARKI LAMBS FED Kochia indica IN SINAI Abdel-Fattah, M.S. ${ }^{1}$; A.A. Azamel ${ }^{1}$ and K.M.A.Ibrahim ${ }^{2}$ 1.Animal Physiology Department, Animal and Poultry Production Division, Desert Research Center, Matariya, Cairo, Egypt. \\ 2.Plant and Range Management Department, Desert Research Center, Matariya, Cairo, Egypt.
}

\begin{abstract}
This work was conducted at Ras Sudr Research Station, which locates in South Sinai Governorate, belonging to Desert Research Center, to investigate the effect of short- term feeding (90 days) Barki lambs on Kochia indica shrubs as forage (treated group, T) compared with clover hay (control group, C). The physiological responses were body fluids distribution, water balance, some plasma electrolyte concentrations (Sodium, $\mathrm{Na}^{+}$and Potassium, $\mathrm{K}^{+}$), in-vivo body composition and growth performance during summer.

The results revealed that, live body weight (LBW) changes over the experimental period were generally positive in both $T$ and $C$ groups without significant difference. The rates of LBW change in the two experimental groups represented +32.79 and $+32.97 \%$, respectively. Regarding the effect of period on body fluids distribution, the rates of changes in total body water (TBW), extracellular fluids (ECF), intracellular fluids (ICF) and interstitial fluids (ISF) were highly significant $(P<0.01)$ in the two groups with values being $+36.27,+24.68,+43.37$ and $+18.33 \%$ vs. $+36.27,+33.25$ +38.47 and $+32.43 \%$ respectively for $\mathrm{T}$ and $\mathrm{C}$ groups.

The averages of daily-retained water were 44.6 and $46.6 \mathrm{~g} / \mathrm{head}$ for $\mathrm{T}$ and $\mathrm{C}$ groups with respective ratios of daily gain in live body weight of 65.8 and $68.7 \%$. Plasma electrolytes showed that lambs fed Kochia indica elevated plasma $\mathrm{Na}^{+}$ concentration $(\mathrm{P}<0.01)$, while control group kept their plasma $\mathrm{Na}^{+}$concentration approximately constant. Plasma $\mathrm{K}^{+}$concentration increased significantly for both groups, with higher increase in lambs fed Kochia indica $(+26.38 \%)$ than lambs fed clover hay $(+2.71 \%)$.

By the end of experimental period, the mean values of plasma, blood and red cells volumes increased in both groups, this increase was more for lambs fed Kochia indica than those fed clover hay.

For the Antipyrine dilution technique, the prediction equations showed no variations in body composition and growth performance between treated and control groups. Also results showed no significant effect for Kochia indica on in-vivo body composition fractions since total body protein (TBP), total body fat (TBF) and total body ash (TBA) increased throughout the experimental period $(P<0.01)$ without significant differences between treated and control groups. The averages of daily body weight gain throughout the study period were the same values of $67.8 \mathrm{~g} / \mathrm{h} / \mathrm{d}$ in the two groups. Water balance indicated that lambs fed Kochia indica showed higher water turnover rate i.e total water intake and excretion $(\mathrm{P}<0.01)$ compared to the control group.
\end{abstract}

Keywords: sheep, Kochia indica, body fluids, in-vivo body composition and water balance 


\section{INTRODUCTION}

The use of halophytes for fodder production may be one of means of utilizing salt affected soils. Kochia indica is a salt and/or drought tolerant shrubs, which produced in great biomass during dry season (Sherrod, 1973; Zahran, 1986 and Abou Zaida, 1988).

Fahmy and fayed (2000) reported that, both sheep and goats were in a good nutritional status when fed on Kochia indica diet and it could be highly recommended to use Kochia indica hay particularly during the summer season as good quality roughage instead of berseem hay. Similarly, Fahmy and Ibrahim (2005-b) and Tag El-Din et al. (1991) mentioned also that Kochia indica could be used as a good green fodder for ruminants due to its comparable content of crude protein to clover hay, which is becoming scare and expensive.

This work was designed to estimate growth performance, in-vivo body fluids distribution, in-vivo body composition, plasma electrolytes $\left(\mathrm{Na}^{+}, \mathrm{K}^{+}\right)$ concentrations and water balance for growing Barki lambs fed cultivated Kochia indica in comparison with those fed clover hay as a basal roughage diet during summer season in Southern Sinai.

\section{MATERIALS AND METHODS}

The present study was carried out at the Experimental Farm of Ras Sudr Research Station, which located in South Sinai Governorate, belonging to Desert Research Center. The soil in this farm is characterized as loamy sand texture containing total salinity of $6100 \mathrm{ppm}$.

\section{Plant material:}

Clover hay was used as a control diet (C) while fresh Kochia indica shrubs used as treated diet $(\mathrm{T})$. Kochia indica shrubs were cultivated in agronomic plots in Ras Sudr Experimental Farm. Organic manure was applied during soil preparation with rate of $40 \mathrm{~m} 3 / \mathrm{fed}$. Kochia indica was irrigated weekly using underground brackish well water. Kochia indica shrubs were daily harvested in the morning and mechanically chopped and used fresh.

\section{Experimental animals and design:}

Sixteen growing male Barki lambs at 6 months old with initial average body weight of $18.5 \pm 2.55 \mathrm{~kg}$ were used for 90 -day experiment in summer (from August to October). They were allocated randomly into two equal groups (8lambs/group). The two groups were kept separately in shaded pens. The first group as control received ad lib clover hay (C), while the second as a treated group was fed ad lib, fresh Kochia indica ( $\mathrm{T})$. The roughage materials were offered twice daily (at 08:00 and 15:00 hr). Both two groups were supplemented with concentrate feed mixture (CFM) equal to $100 \%$ of its energy maintenance requirements according to Kearl (1982). The concentrate was offered once daily. Fresh drinking water was available ad lib, twice daily. 


\section{Sampling methods:}

At the beginning and the end of study, in-vivo total body water (TBW) was estimated using antipyrine space method according to Brodie et al. (1949) and extracellular fluids (ECF) was estimated using sodium thiocyanate method according to Bowler, (1944). Plasma volume was determined by the method of Kennedy and Millikan, (1938) using the Evan's blue dye (T-1824). Intracellular fluid (ICF) volume was calculated by deduction (TBW - ECF), Interstitial fluid (ISF) volume was obtained by subtracting PV from ECF. Plasma electrolyte concentrations $(\mathrm{Na}+, \mathrm{K}+)$ were estimated using Flame photometric method (Hawk et al. 1965).

Antipyrine (1-phenyl-2, 3-dimethyl-5pyrazolone) was employed in a dilution technique for the determination of total body water. TBW was calculated according to the following equation suggested by (Panaretto and Till, 1963). TBW= Antipyrine-space $-0.03 \times$ body weight.

Average daily-retained water (ADRW) was calculated by difference as follows: $\quad$ ADRW, $g=($ Final TBW - Initial TBW $) / 90$ days.

\section{Prediction of body chemical composition:}

The prediction equations using total body water (TBW) to calculate body composition fractions according to Fekry et al. (1989) as follows:

Total body fat, $(\mathrm{TBF})=$ Body weight, $\mathrm{kg}$ - Fat-free body, $\mathrm{kg}$

Fat -free body, $\mathrm{kg}=\mathrm{TBW} / 0.736$

Fat-free dry solids, $\mathrm{kg}=$ TBW - Fat-free body;

Total body ash, $($ TBA $)=$ TBP- Fat-free dry solids

Total body protein, $(\mathrm{TBP})=$ Fat-free dry solids, $\mathrm{kg} \times 0.788$

Blood samples were taken in the morning before access to feed and water. An initial blood sample was taken from the right jugular vein. A portion of the initial blood sample was transferred to a Wintrobe tubes, centrifuged for 20 minutes at $3500 \mathrm{rpm}$ and the packed cell volume determined according to Dacie and Lewis, (1991). The rest of samples were centrifuged at $3500 \mathrm{rpm}$ for 20 minutes to collect plasma and stored at $-20 \mathrm{C}$ for biochemical analysis.

After 75 days of the experimental period four lambs of each group were randomly chosen and placed in metabolic cages with capability of collecting urine and fecal output separately for water balance study. One week was given for adaptation of animal to metabolic cage; this period was followed by seven days collection period. Refusals of both roughage and concentrate rations were collected every day before offering fresh feed. The total water intake was calculated each day by adding free water intake to its amount in food intake. The water balance defined as total water input (free, food and metabolic water) minus the measured output (urine and fecal moisture).

\section{Statistical analysis:}

Data were analyzed using the SAS software (SAS Institute, 1998). The repeated measurements analysis of variance (Procedure MIXED) was applied to the respective parameters. Differences among means were examined using Multiple Range Test according to Duncan, (1955). 


\section{RESULTS AND DISCUSSION}

\section{Changes in live body weight and body fluids distribution:}

Live body weight (LBW) changes as indicators to animal growth performance in the two studied groups are presented in Table 1. Lambs of both groups have grown in almost the same trend where body weight of lambs increased from initial value of 18.5 to $24.6 \mathrm{~kg}$ by the end of the study for Kochia indica -fed group, versus values from 18.6 to $24.7 \mathrm{~kg}$ for clover hayfed group. The averages of body weight gain throughout the study period were of the same value of $67.8 \mathrm{~g} / \mathrm{h} / \mathrm{d}$ in the two groups. This finding is completely in agreement with that of Fahmy and Ibrahim, (2005-b) on Barki male lambs, Gabr, (2002) on Barki ewe lambs and Atiq-ur-Rehman, (2002) on Merino wethers.

At the start of study, total body water (TBW) composed approximately $55.73 \%$ of LBW for lambs fed Kochia indica vs. $56.18 \%$ for lambs fed clover hay. At the end of study (90 days) TBW reached to 57.11 and $57.6 \%$ for the two groups, respectively. Statistical tests revealed that, there were no significant differences on LBW and TBW between the two studied groups throughout the experimental period.

In respect of body fluids components, values of TBW, ECF, ICF and ISF at the beginning of study were similarly in both treated and control groups (Initial values in Table, 1). Concerning the effect of the experimental period on body fluids distribution, control group showed higher changes $(P<0.01)$ than treated group on ECF $(+33.25$ vs. $+24.68 \%)$ and ISF $(+32.43$ vs. $+18.33)$, while treated group showed higher $(P<0.01)$ value of ICF $(+43.37$ vs. $+38.47 \%$ ). Abd El-Gawad. et al. (1997) reported that, ECF and ISF increased significantly $(P<0.01)$ in Barki goats watered saline well-water, and these increases could be attributed partly to higher intake of saline water.

Changes in plasma electrolytes (Sodium, $\mathrm{Na}+$ and Potassium, $\mathrm{K}+$ ) concentrations:

The results (Table1) showed that lambs fed Kochia indica elevated plasma $\mathrm{Na}+$ concentration $(\mathrm{P}<0.01)$, while control group remained their plasma $\mathrm{Na}+$ concentration nearly constant along the experimental period. However, plasma $\mathrm{K}+$ concentration increased more $(\mathrm{P}<0.01)$ for $\mathrm{T}$ group than C one.

Regarding the effect of period on plasma electrolytes, the rates of change from initial to final values of $\mathrm{Na}+$ and $\mathrm{K}+$ were +8.72 and $+26.78 \%$ for $\mathrm{T}$ group vs. -0.99 and $+2.71 \%$ for $\mathrm{C}$ group, respectively. The elevation in plasma $\mathrm{Na}+$ and $\mathrm{K}+$ concentrations for Kochia indica group might be due to the effect of higher sodium percentage in $\mathrm{T}$ ration (1.96\%) than $\mathrm{C}$ ration (1.61\%) in Table 4 or might be due impairment in renal function in the form of decrease in glomerular filtration rate which led to increase in plasma $\mathrm{Na}+$ and $\mathrm{K}+$ concentrations in treated group. These results are in agreement with the findings of Badawy et al. (2002) on Barki lambs and Baladi kids and Abd ElGawad, et al (1997) on Barki and Damascus goats. The results of Khamis et al. (1989) and Hagsten and Perry (1979) on sheep indicated that drinking saline water increased plasma sodium and potassium concentrations. 
Table (1): Means \pm SE of live body weight (LBW), total body water (TBW), extracellular fluids (ECF), intracellular fluids (ICF), interstitial fluids (ISF) and plasma electrolyte $(\mathrm{Na}+, \mathrm{K}+)$ concentrations in lambs fed Kochia indica (T) or clover hay (C)

\begin{tabular}{|c|c|c|c|c|c|c|}
\hline \multirow{3}{*}{ Item } & \multicolumn{4}{|c|}{ Periods } & & \\
\hline & \multicolumn{2}{|c|}{ Initial } & \multicolumn{2}{|c|}{ Final } & \multicolumn{2}{|c|}{ Changes $\%$} \\
\hline & C & $\mathbf{T}$ & C & $\mathbf{T}$ & C & $\mathrm{T}$ \\
\hline LBW (kg) & 18.6 & 18.5 & 24.7 & 24.6 & $32.79^{\star *}$ & $32.97^{\star \star}$ \\
\hline (SE) & & & & & & \\
\hline TBW (L) & 10.45 & 10.31 & 14.20 & 14.05 & $36.27^{\star \star}$ & $36.27^{\star \star}$ \\
\hline (SE) & & & & & & \\
\hline ECF (L) & 4.15 & 3.89 & 5.53 & 4.85 & $33.25^{\star \star}$ & $24.68^{\star}$ \\
\hline (SE) & & & & & & \\
\hline ICF (L)) & 6.29 & 6.41 & 8.71 & 9.19 & $38.47^{*}$ & $43.37^{\star \star}$ \\
\hline (SE) & & & & & & \\
\hline ISF (L) & 3.33 & 3.11 & 4.41 & 3.68 & $32.43^{\star \star}$ & $18.33^{\star}$ \\
\hline (SE) & & & & & & \\
\hline $\mathrm{Na}+(\mathrm{mEql} / \mathrm{L})$ & 152 & 146.8 & 150.5 & 159.6 & $-0.99 N S$ & $8.72^{\star \star}$ \\
\hline (SE) & & & & & & \\
\hline $\mathrm{K}+(\mathrm{mEql} / \mathrm{L})$ & 5.52 & 5.95 & 5.67 & 7.52 & $2.71^{\star}$ & $26.38^{\star \star}$ \\
\hline (SE) & & & & & & \\
\hline
\end{tabular}

C: consists of clover hay plus concentrate feed mixture

T: Consists of fresh Kochia indica plus concentrate feed mixture

SE $=$ standard error $\quad$ NS $=$ non-significant $\quad{ }^{*}=(P<0.05) \quad{ }^{* *}=(P<0.01)$

Ahmed et al. (1985) reported higher retention of potassium in Barki rams watered saline water (9100ppm).

Changes of blood, plasma, red cells volumes and hematocrit (\%):

The results in Table 2 revealed that, intravascular fluids (plasma and blood volumes) were higher in lambs fed Kochia indica than lambs fed clover hay, these increases were proved to be more significant $(P<0.01)$ at the end of study. The rates of change of PV and BV were 48.29 and $49.53 \%$ for T group vs. 39.55 and $36.61 \%$ for $C$ group, respectively. The higher plasma volume could be due to the increase in salt intake, which increased plasma sodium content due to the absorption of sodium across the gut wall. This would have caused the movement of fluid from the interstitial fluid and gut into the plasma to maintain the osmolarity pressure gradient between compartments (Harper et al. 1997) thus increasing blood volume. Similar results obtained by Abd ElGawad et al. (1997) on goats, reported that, plasma and blood volumes increased $(P<0.01)$, this increase could be attributed partly to higher intake of saline well water. On contrast, Nasr et al. (2002) reported that, PV and BV decreased in goats fed Atriplex halimus. 
Abdel-Fattah, M.S. et al.

Table (2): Means \pm SE of plasma volume (PV), blood volume (BV), red cells volume $(\mathrm{RCV})$ and hematocrit $(\mathrm{Ht})$ values in lambs fed clover hay or Kochia indica

\begin{tabular}{|c|c|c|c|c|c|c|c|}
\hline & \multicolumn{4}{|c|}{ Periods } & \multirow{3}{*}{$\frac{(\mathrm{SE})}{( \pm)}$} & \multicolumn{2}{|c|}{ Changes\% } \\
\hline Item & & & & & & & \\
\hline & C & $\bar{T}$ & C & $\mathbf{T}$ & & C & $T$ \\
\hline PV (L) & 0.817 & 0.789 & 1.14 & 1.17 & \pm 0.05 & $39.53^{\star \star}$ & $48.29^{\star \star}$ \\
\hline$\%$ of LBW & 4.41 & 4.26 & 4.6 & 4.75 & & 0.19 & 0.5 \\
\hline BV (L) & 1.12 & 1.07 & 1.53 & 1.60 & \pm 0.07 & $36.61^{\star \star}$ & $49.53^{\star \star}$ \\
\hline$\%$ of LBW & 6.0 & 5.78 & 6.1 & 6.5 & & 0.1 & 0.72 \\
\hline RCV (L) & 0.299 & 0.282 & 0.399 & 0.433 & \pm 0.02 & $31.44^{\star \star}$ & $53.55^{\star \star}$ \\
\hline$\%$ of LBW & 1.61 & 1.52 & 1.61 & 1.76 & & 0.0 & 0.24 \\
\hline Ht (\%) & 26.75 & 26.25 & 25.63 & 27.0 & \pm 0.15 & -4.19 & $2.86^{*}$ \\
\hline
\end{tabular}

C: consists of clover hay plus concentrate feed mixture $\quad$ SE $=$ standard error $\quad{ }^{*}=$ $(P<0.05) \quad$ ** $=(P<0.01)$

T: Consists of fresh Kochia indica plus concentrate feed mixture

Regarding the effect of period, the mean values of $\mathrm{PV}, \mathrm{BV}$ and $\mathrm{RCV}$ increased $(P<0.01)$ from initial to the end of study for both $T$ and $C$ groups. However, these values were nearly constant relative to the LBW at the same occasions of measuring. At the start of the study, the percentages of PV, BV and RCV were $4.26,5.78$ and $1.52 \%$ for T group vs. $4.41,6.0$ and $1.61 \%$ for $\mathrm{C}$ group, respectively. The corresponding values at the end of study were $4.75,6.5$ and $1.76 \%$ vs. $4.6,6.1$ and $1.61 \%$. On contrast, Singh and Taneja, (1978) reported that, Marwari ewes provided different levels of salinity in drinking water exhibited no signs of change in their blood volume over a period of six months.

The results (Table, 2) indicated that no significant effect of treatment on hematocrit value. This result was in agreement with the finding of Nasr et al. (2002). Likewise, Azamel (1997) and Badawy et al. (2002) reported that, the values of packed cell volume of lambs and kids fed Atriplex and Acacia lied within the normal range reported for sheep and goats. Statistical analysis showed significant increase $(P<0.05)$ in hematocrit value as percentage from initial value in lambs fed Kochia indica by the end of experimental period.

\section{Changes in predicted body compositions:}

In-vivo body composition is essential for studying both the growth performance and body development. It is known that, there are high correlations between the body weight and the weights of its components. That body composition could be predicted from body weight and total body water in animals of the same breed and even consuming different amounts of the same diet. Although, animals under study was of the same breed but fed on different roughage diets, the rates of change in body composition (TBP, TBF and TBA) were approximately similar (Table 3 ) and this may prove the nutritive value of Kochia indica and clover hay were much similar. Fahmy and Ibrahim, (2005-b) reported that, concentrations of crude protein and potassium were similar between Kochia indica and clover hay. Moreover, 
digestibility of dry matter, crude protein and crude fiber were greater for Kochia indica than clover hay.

Table (3): Means \pm SE of total body protein (TBP), total body fat (TBF) and total body ash (TBA) in lambs fed clover hay or Kochia indica

\begin{tabular}{|r|c|c|c|c|c|c|c|}
\hline Item & \multicolumn{3}{|c|}{ Periods } & (SE) & \multicolumn{2}{c|}{ Changes\% } \\
\hline & \multicolumn{2}{|c|}{ Initial } & \multicolumn{2}{c|}{ Final } & & \multicolumn{2}{c|}{ Chang } \\
\hline & C & T & C & T & & C & T \\
\hline TBP (Kg) & 2.95 & 2.91 & 4.02 & 3.97 & \pm 0.15 & $\mathbf{3 6 . 2 7}$ & $\mathbf{3 6 . 4 3}^{\text {NS }}$ \\
\hline & & & & & & & \\
\hline TBF (Kg) & 4.43 & 4.49 & 5.35 & 5.47 & \pm 0.14 & $\mathbf{2 0 . 7 7}$ & $\mathbf{2 1 . 8 3 ^ { \text { NS } }}$ \\
\hline & & & & & & & \\
\hline TBA (Kg) & 0.795 & 0.784 & 1.08 & 1.07 & \pm 0.04 & $\mathbf{3 5 . 8 5}$ & $\mathbf{3 6 . 4 8}^{\text {NS }}$ \\
\hline
\end{tabular}

C: consists of clover hay plus concentrate feed mixture $\quad$ SE = standard error NS= non-significant

$\mathrm{T}$ : Consists of fresh Kochia indica plus concentrate feed mixture

Regarding the effect of treatment on body composition, few studies are available. Statistical analysis indicated that, no significant differences were found in the predicted in-vivo body composition (TBP, TBF and TBA). Also, no particular trend observed between two groups of animals under study. The rates of changes were $+36.4,+21.83$ and $+36.48 \%$ for TBP, TBF and TBA for lambs fed Kochia indica versus $+36.27 ;+20.77$ and $+35.85 \%$ for lambs fed clover hay, respectively. Itoko et al. (2006) on cattle and Buffaloes, found that The $48 \mathrm{~h}$ of water deprivation affected the mobilization of body fat and protein, but with no significant difference among animal species in the change of empty body composition, while Abdel-Fattah (1994) on sheep found that, TBP and TBA increased significantly $(P<0.01)$ by increasing the level of salinity in drinking water in summer and winter.

\section{Feed and water intakes:}

Chemical composition and mineral contents of feed ingredients and tested rations (\% on DM basis) are given in Table 4. The present results regarding the chemical composition of Kochia indica are close to the findings of Nour (1995) and Shehata et al. (2001). The mean of total feed intakes ( \pm SE) for lambs fed Kochia indica (Table 5$)$ was greater $(P<0.01)$ than those consumed by control group. This increase was attributed to the increase $(P<0.01)$ intake of Kochia indica in fresh matter compared with clover hay. Fahmy and Ibrahim, (2005-b) found that, Barki lambs consumed more dry matter and organic matter amounted to 31.9 and $29.9 \%$ from Kochia indica than clover hay, respectively. Nour (1995) found that, when fresh Kochia indica was fed as a sole diet of adult Rahmany rams, the dry matter intake was higher $(P<0.01)$. The results indicated that, the total digestible nutrient (TDN) was $542 \mathrm{vs} .469 \mathrm{~g} / \mathrm{head} /$ day and the digestible crude protein (DCP) was $81.2 \mathrm{vs}$. $67.1 \mathrm{~g} / \mathrm{head} /$ day for lambs fed Kochia indica compared to those of clover hay groups, respectively (Table5). This result was in agreed with Fahmy and Ibrahim, (2005-b) on Barki lambs. 
Abdel-Fattah, M.S. et al.

Table (4): Chemical composition and mineral contents of feed ingredients and tested rations on dry matter basis (\%)

\begin{tabular}{|l|c|c|c|c|c|c|c|c|c|}
\hline Item & DM & CP & CF & EE & NFE & Ash & OM & Na+ & K+ \\
\hline Clover hay & 89 & 13.9 & 29.6 & 3.90 & 38.5 & 14.1 & 85.9 & 2.52 & 1.96 \\
\hline Kochia indica & 39.9 & 12.5 & 27.0 & 3.53 & 41.17 & 15.8 & 84.2 & 2.96 & 1.81 \\
\hline CFM & 90 & 15.5 & 25.7 & 3.61 & 46.99 & 8.20 & 91.8 & 0.80 & 1.37 \\
\hline C ration & 89.5 & 14.7 & 27.5 & 3.74 & 43.16 & 10.9 & 89.0 & 1.61 & 1.65 \\
\hline T ration & 63.1 & 13.9 & 26.4 & 3.57 & 43.83 & 12.3 & 87.6 & 1.96 & 1.60 \\
\hline
\end{tabular}

C ration: consists of clover hay plus concentrate feed mixture $\mathrm{CF}=$ crude fiber EE= ether extract

$T$ ration: Consists of fresh Kochia indica plus concentrate feed mixture DM= dry matter, $\mathrm{CP}=$ crude protein,

$\mathrm{NEF}=$ nitrogen free extract $\mathrm{OM}=$ organic matter $\quad \mathrm{Na}^{+}=$sodium $\mathrm{K}^{+}=$potassium

Table (5): Means \pm (SE) of feed and water intakes in lambs fed clover hay (C) or kochia indica (T) during water balance study

\begin{tabular}{|c|c|c|c|c|}
\hline & \multicolumn{2}{|c|}{ Experimental groups } & \multirow[t]{2}{*}{ SE ( \pm ) } & \multirow[t]{2}{*}{ T test } \\
\hline Item & $\mathbf{C}$ & $\mathbf{T}$ & & \\
\hline Concentrate & 0.535 & 0.537 & 0.28 & NS \\
\hline Roughage, Kg (base a dry matter) & $\begin{array}{c}0.509 \\
---\end{array}$ & $\begin{array}{c}0.853 \\
(1.42 \mathbf{\Delta})\end{array}$ & 1.24 & ** \\
\hline Total feed intake, $\mathrm{Kg}$ (base a dry matter) & 1.044 & 1.390 & 1.35 & ** \\
\hline Dry matter intake (g/Kg BW) & 42 & 52 & 0.02 & $\star \star \star$ \\
\hline $\begin{array}{l}\text { Digested nutrients intake: } \\
{ }^{*} \text { TDN, g/head/day } \\
\text { * DCP }, \text { g/head/day }\end{array}$ & $\begin{array}{l}469 \\
67.1\end{array}$ & $\begin{array}{l}542 \\
81.2\end{array}$ & $\begin{array}{l}1.59 \\
0.41\end{array}$ & $\underset{*}{N S}$ \\
\hline Free water intake $(\mathrm{L} / \mathrm{h} / \mathrm{d})$ & 4.207 & 4.352 & 0.04 & * \\
\hline Free water intake (ml/g DMI) & 4.03 & 3.13 & 15.8 & * \\
\hline
\end{tabular}

C: consists of clover hay plus concentrate feed mixture; $\Delta=$ Kochia indica as a forge ${ }^{*}=$ $(P<0.05)$

TDN = Total digestible nutrient

DCP = digestible crude protein

T: Consists of fresh Kochia indica plus concentrate feed mixture NS= non-significant ${ }^{* *}=\mathrm{p}<0.01$

Free water intakes for lambs fed Kochia indica and those fed clover hay were 4.352 and $4.207 \mathrm{~L} /$ head/day. The results in Table 6 and statistical analysis revealed that, there was significant increase $(P<0.01)$ in free water intake for lambs fed Kochia indica compared with those fed clover hay. These results were in agreement with the results of Abou-El Nasr et al (1988) and Sooud et al. (1993) on sheep, goat and camels. The results in Table 5 revealed that, values of free water intake represented 3.13 and $4.03 \mathrm{ml} / \mathrm{g}$ of DMI for lambs fed Kochia indica and those fed clover hay, respectively.

Water balance:

Regarding the water balance components (Table 6), Total water intake consisted of $4.352 ; 1.233$ and $0.3252 \mathrm{~L} /$ head/day for free; feed and metabolic water, respectively for lambs fed Kochia indica. The corresponding values for lambs fed clover hay were $4.207 ; 0.935$ and $0.2814 \mathrm{~L} / \mathrm{head} /$ day. These results revealed that, feed water is greater $(\mathrm{P}<0.05)$ for lambs fed Kochia indica than for those fed clover hay due to higher moisture percentage (dry mater of Kochia indica equal to $39.9 \%$, Table 4). 
Total water intake significantly $(P<0.01)$ varied between the two diets. The total water intake followed the same trend of feed water intake. Such results are in agreement with those reported by Hassan et al. (1982); ElShaer and kandil, (1990); El-Shaer et al. (1991) on sheep and goat, Shawket et al. (2002) on lambs and kids, Fahmy and Ibrahim, (2005-b) on Barki lambs.

Table (6): Water balance for Barki lambs fed clover hay (C) or Kochia indica $(\mathrm{T})$ during summer season

\begin{tabular}{|c|c|c|}
\hline (2) - & \multicolumn{2}{|c|}{ Experimental groups } \\
\hline Variable & $\mathbf{C}$ & $\mathrm{T}$ \\
\hline Free water intake (L/d) & 4.207 & 4.352 * \\
\hline Free water intake (ml/kg BW) & 170.32 & 176.91 \\
\hline Feed Water intake (L/d) & 0.935 & $1.233^{*}$ \\
\hline Feed Water intake (ml/kg BW) & 37.84 & $50.12^{\star \star}$ \\
\hline Metabolic water intake (L/d) & 0.2814 & 0.3252 \\
\hline Metabolic water intake (ml/kg BW) & 11.39 & 13.22 \\
\hline Total water intake (L/d) & 5.423 & $5.9102^{* *}$ \\
\hline Total water intake (ml/kg BW) & 219.55 & 240.25 \\
\hline Water loss via urine (L/d) & 1.306 & $1.986^{\star \star}$ \\
\hline Water loss via feces (L/d) & 0.413 & $0.518^{*}$ \\
\hline Total water losses (L/d) & 1.719 & $2.504^{\star \star}$ \\
\hline Total water losses (ml/kg BW) & 69.59 & 101.79 \\
\hline Water balance (ml/kg BW) & 149.96 & 138.46 \\
\hline
\end{tabular}

Metabolic water $=$ one gram TDN intake produce $0.6 \mathrm{ml}$ metabolic water (English,1966).

For lambs fed Kochia indica, total water loss consisted of 1.986 and $0.518 \mathrm{~L} / \mathrm{head} /$ day for urinary water and fecal moisture, respectively. The corresponding values for lambs fed clover hay were 1.306 and 0.413 /head/day. According to water balance values in Table 6, urinary water excretion increased as the increase of water intake in lambs fed Kochia indica compared with lambs fed clover hay. Kandil et al. (1985) reported that, urinary water excretion increased as the increase of water, respectively for lambs fed Kochia indica. The corresponding values for lambs fed clover hay were $4.207 ; 0.935$ and $0.2814 \mathrm{~L} / \mathrm{head} /$ day. These results revealed that, feed water is greater $(P<0.05)$ for lambs fed Kochia indica than for those fed clover hay due to higher moisture percentage (dry mater of Kochia indica equal to $39.9 \%$, Table 4$)$. Total water intake significantly $(P<0.01)$ varied between the two diets. The total water intake followed the same trend of feed water intake. Such results are in agreement with those reported by Hassan et al (1982); El- 
Shaer and kandil, (1990); El-Shaer et al. (1991) on sheep and goat, Shawket et al. (2002) on lambs and kids, Fahmy and Ibrahim, (2005-b) on Barki lambs.

Water intake resulting high water turnover rate. The same pattern was observed on the fecal moisture and consequently on the total water excretion in camels as effected by drinking saline water. El-Faramawy (1984) and Abdel-Fattah, (1994) found that, urine volume of saline-watered sheep was significantly $(\mathrm{P}<0.01)$ higher than that of the control group by all the levels of salinity in drinking water. Increasing water excretion through the urinary pathway is believed to be an adaptive mechanisms assisting the animal to get rid of excess salts and maintaining the osmolarity of blood and other body fluids (Ahmed, 1984). Water excretion via faeces in the two groups showed similar trend and recorded lower values of 0.518 vs. $0.413 \mathrm{~L} /$ day in lambs fed Kochia indica compared with lambs fed clover hay.

Water balance for lambs fed Kochia indica retained $+138.46 \mathrm{ml} / \mathrm{kg} \mathrm{LBW}$, versus $+149.96 \mathrm{ml} / \mathrm{kg}$ LBW for lambs fed clover hay. These results showed that, the animals fed Kochia indica remained water balance near to the control group, accordingly it could be expected that, the treated group had tolerant thermoregulation similar to the control group under heat stress of the desert. The same findings were reported by Hamed et al. (2007).

The results in Table 6 and statistical analysis revealed that, there was an apparent increase $(P<0.01)$ in each of water intake and water output in lambs fed Kochia indica compared with lambs fed clover hay. These results were in agreement with the results obtained by Abou-El Nasr et al. (1988) and Sooud et al. (1993) on sheep, goat, and camels.

\section{CONCLUSION}

When growing Barki lambs were subjected to salt stress in Kochia indica for 90-day experiment during summer season, live body weight (LBW) change was generally positive without significant differences between control and treated groups. Also, values of total body water (TBW), extracellular fluids (ECF), intracellular fluids (ICF) and interstitial fluids (ISF) were similarl in both groups of lambs fed Kochia indica and those fed clover hay. For prediction of body composition and growth performance by Antipyrine dilution technique, this method explained no variations between treated and control groups. Water balance indicated that lambs fed Kochia indica showed higher water turnover rate or higher total water intake and excretion $(P<0.01)$ compared to the control group.

\section{ACKNOWLEDGMENT}

The authors wish to special thanks are given to Dr. Alsheikh, S. M. Researcher at Department of Animal Breeding for his assistance in statistical analysis 


\section{REFERENCES}

Abd El-Gawad Eman; M.I. Yousef, and A.E. Haider (1997). Body water distribution and plasma elyctrolytes as affected by saline drinking water in Barki, Damascus and their crossbred goats. J. Agric.Sci. Mansoura Univ., 22 (5): 1413-1424.

Abdel-Fattah, M. S. (1994). Environmental stress in ruminants. Ph. D. Thesis, Fac. Of Agric. Cairo Univ. El-Fayoum Branch, Egypt.

Abou-El-Nasr H.M.; Sawket, Safinaz M.; M.F.A. Farid and H.S. Khamis (1988) Studies on saline drinking water for camels and sheep: I. Water intake and excretion. Communication in Science \& Development. Res. Vol. (23).

Abu Zaida, M.E.A. (1988) Autecological and phytochemical studieson Kochia indica weight M.Sc. Thesis Faculty of Science, Mansoura University, Egypt.

Ahmed, M.H. (1984) Studies on nitrogen metabolism in ruminant. Effect of drinking saline wateron nitrogen metabolism and rumen. Ph. D. Thesis, Alexandria Univ., Fac. Of Agric., Egypt.

Ahmed, M.H; M.F.A. Farid; N.I. Hassan; B.E. Borhami and M. Shawket, Safinaz(1985) Effect of drinking saline well water in sheep. I. Feed and nitrogen utilization and mineral balance. First International Conference on Animal Production in Arid Zones (ICAPAZ). Sep.,7-14., ACSAD. Damascus.Syria., pp. 893-905.

Atiq-ur-Rehman (2002) Utilization of Atriplex as aforage under grazing and cut and carry systems for small ruminants. International symposium on Optimum Resources Utilization in Salt-Affected Ecosystems in Arid and Simi Arid Regions, Cairo, Egypt.8-11 April 426-431.

Azamel, A.A. (1997) Physiological responses and daily gain of growing Barki lambs fed on Atriplex halimus, a natural desert shrub. Egypt. J. Appl. Sci., 37:71-81.

Badawy,M.T.A.,H. A. Gawish and A. A. Younis (2002). Some physiological responses of growing Barki lambs and Baladi kids fed natural desert under shrubs. International symposium on Optimum Resources Utilization in Salt-Affected Ecosystems in Arid and Simi Arid Regions, Cairo, Egypt.8-11 April 496-503.

Bowler, R.G.(1944). The determination of thiocyanate in blood serum. Biochem. J., 38: 385-388.

Brodie,B.B.; J. Axelord ;R. Soberman; and B. Levy Betty (1949). The estimation of antipyrine in biological materials. $\mathrm{J}$ of Biology. Chemistry 179: 25.

Dacie, S.T. and S.M. Lewis (1991). Basic Hematological Techniques in Practical Hematology 7th ed. Churchill Livingston. Medical Division of Longman Group, U>K> Ltd., pp.36-66.

Duncan, D.B. (1955). Multiple ranges and multiple F-test. Biometrics, 11:124. 
El- Shaer, H.M. and H.M. Kandil (1990) Comparative study on the nutritional value of wild and cultivated Atriplex halimus by sheep and goat in Sinai. Comp.Sci. and Dev.Res.29:881-90.

El- Shaer, H.M.; H.M. Kandil and H.S. Khamis (1991) Salt marsh plants ensiled with dried broiler litter as a feedstuff for sheep and goats. Agric. Scii.Mansoura Univ., 16 (3): 1524-1534.

El-Faramawy, A.A. (1984) Effect of drinking bring water on energy and water metabolism in sheep. M.Sc. Thesis, Fac. of Sci., Ain Shams Univ., Egypt.

English,P.B.(1966) A study of water and electrolytes metabolism in sheep. I. External balance of water, sodium, potassium and chloride. Res. Vet. Sci., 7:233.

Fahmy, A.A. and Afaf, M.Fayed (2000) Nutritional evaluation of Kochia indica hay as animal feed in Sinai. Egyptian J. Nutrition and Feeds. 3: 97.

Fahmy, A.A. and K.M.A. Ibrahim (2005-a) Feed utilization and performance of lambs fed Kochia indica shrubs under desert conditions of Sinai. Egyptian,J. Desert Res., 55, No.1, 153-163.

Fahmy, A.A. and K.M.A. Ibrahim, (2005-b) Nutritional studies on the use of Kochia indica shrubs for feeding lambs in Sinai. Egyptian,J. Desert Res., 8, No.1, Special Issue 337-347.

Fekry, A.E.; O.A.I. Salem; M.A. Hanafy and G.M. Abdul-Aziz (1989) Effect of antibioyics supplementation on growth, body composition and hematological parameters of growing sheep. Proc. 3rd Egyptian-British Conf. Anim. Fish and Poult. Prod. Alexandria, Egypt, (1) p.409.

Gabr,M.G.(2002) First experience of matrouh resource management project (MRMP) in saltbush utilization for animal feeding. International symposium on Optimum Resources Utilization in Salt-Affected Ecosystems in Arid and Simi Arid Regions, Cairo, Egypt.8-11 April 419425.

Hagsten, lb. and T.W. Perry (1979) Effect of dietary sodium levels on blood levels, urinary excretion and adrenal histology of lambs. J. Anim. Sci. 40:1205-1210.

Hamed, M.H. ; M.S. Abdel-Fattah ;H.A. Gawish and M.T.A. Badawy (2007) Changes in body fluids and water balance of desert sheep and goats during water restriction. Egypt. J. Basic Appl. Physiol., 6(2): 361-374.

Harper ME, JS Willis and J Patrick (1997) Sodium and chloride in nutrition. In " Handbook of Nutritionally Essential Mineral Elements". (Eds BL O"Dell and RA Sunde) pp.93-116. (Marcel Dekker: New York).

Hassan, N.L.; H.M. El-Shaer and H.M. Kandil (1982) Lambs performance on pasture supplemented with concentrates. World Rev. Anim. Prod., 18: 70-73.

Hawk, P.S.; B.L. Oser and W.H. Summerson (1965). Practical Physiological Chemistry. 14th Ed., Blakiston Co. New York., U.S.A. pp95-102.

Itoko, NONAJKA; Arata KOGA and Masaharu ODAl (2006) Evaluation of the difference in body composition of Thai native cattle and Swamp Buffaloes from that of Holstein cattle in Northeast Thailand using Urea space. JARQ 40 (4), 387-391 
Kandil, H.M.; O.A. Sooud M.A.M. Farid; H.M. El-Shaer and M.A. El-Ashry (1985) Effect of drinking saline water on feed utilization and nitrogen and mineral balance in camels. First International Congress on Animal Production in Arid Zones 9 ICAPAZ, September 7-14, ACSAD, Damascus, Syria.

Khamis, H.S.; M.F.A. Farid, M.H. Ahmed; M. Shawket Safinaz and H.M. Abou El-Nasr(1989) Studies on saline drinking water for camels and sheep. III Sodium and potassium metabolism. Com. Sci. Dev.Res., 25:17-29.

Kearl, L.C. (1982) Nutrient Requirements of Ruminants in Developing Countries. Utah Agric. Exp. Station, Utah State University, Logan, USA.

Kenndy, J.A. and G.A. Millikan (1938). A micro blood volume method using a blue dye and photocell. J.Physiol. (London). 93: 276-284.

Lloyd,L.E.; E. Donfer; A.L. Bowman and E.W. Crampton (1962). Effect of certain forage characteristics on water intake of sheep. J.Anim. Sci. 21: 1063.

Nasr,S.M. ; E.A. Ibrahim ; A.Baker and M.I. Dessouky(2002) clinicopathological and histopathological studies in goats fed on Atriplex halimus raised in the Egyptian desert. International symposium on Optimum Resources Utilization in Salt-Affected Ecosystems in Arid and Simi Arid Regions, Cairo, Egypt.8-11 April 504-514.

Nour, A.A. (1995) Nutritional evaluation of Kochia indica. Alex. J. Agric. Res., 40 (3): 61.

Panaretto,B.A. and A.R. Till (1963). Body composition in vivo. II The composition of mature goats and its relationship to the antipyrine, tritiated water and $\mathrm{N}$-acetyl-4-amino antipyrine spaces. Aust. J. of Agric. Res. 14: 926.

S.A.S,(1998). Statistical analysis system, STAT/user's guide, release 603 ed. SAS Institute, Cary NC. U.S.A.

Shawket, Safinaz M.; M.H. Ahmed; B.E. Borhami and A.M. Allam (2002) A comparative study on the performance of lambs and goat kids fed on halophytic forages supplemented with different sources of energy under arid and semi arid conditions. International symposium on Optimum Resources Utilization in Salt-Affected Ecosystems in Arid and Simi Arid Regions, Cairo, Egypt.8-11 April 450-460.

Shehata, E. I.; M.E. Ahmed; A.M. Abdel Hamid ; Faten F. Abou Amou and M. El Haggag (2001) Comparative nutritive values of silage rations containing different levels of Teosinte and Kochia. Egyptian J. Nutrition and Feeds, 4 (special Issue): 129.

Sherrod, L.B. (1973) Nutritive value of Kochia scoparia. III. Digestibility of Kochia hay compared with alfalfa hay. J. Dairy Science 56: 923.

Singh, N. and G.C. Taneja (1978) Anote on the effect of prolonged salt intake from drinking water on the distribution of body water in Marwari sheep of the Rajasthan desert. Ind. J.Anim.Prod. 17; 537.

Sooud, A.O.; E.A. Helali; A.A. Fahmy and H.A. Sallama (1993) Effect of type diet and drinking saline wateron camels. II. Water utilization and retent6ion of some electrolytes. Proceeding, 4th Symp. Anim.Poult. Fish Nuti. (SOAPFN), November 12-18. El-Fayoum, Egypt page 126. 
Tag El-Din, A.E.; A.A. Nour; M.A. Ahmed and S.M. Zahran, (1991) Utilization of Kochia indica in complete diets for ruminants. Alex. J. Agric. Res., $36: 69$.

Zahran,M.A.(1986) Forage potentialities of Kochia indica and Kochia scoparia in arid lands with particular reference to Saudi Arabia Gulf Journal of Scientific Res.4:53.

$$
\begin{aligned}
& \text { ميزان الماء وتوزيع سوائل الجسم للحملان البرقي المغذاة على نبات الكوخيا انديكا }
\end{aligned}
$$

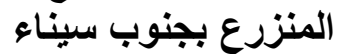

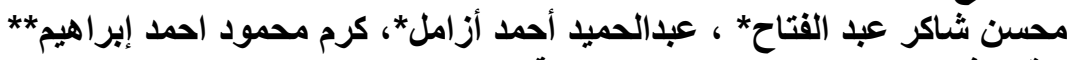

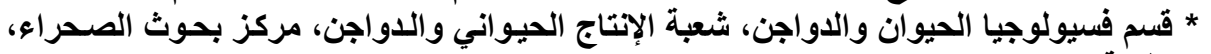

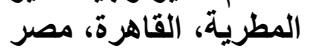

$$
\begin{aligned}
& \text { * قسم البيئة النباتية والمراعى، مركز بحوث الصحراء، المطرية، القاهرة، مصر } \\
& \text { يعتبر الكوخيا انديكا احد نباتات المر اعي الحولية التابعة للعائلة الرمر امية التي تلتحمل }
\end{aligned}
$$

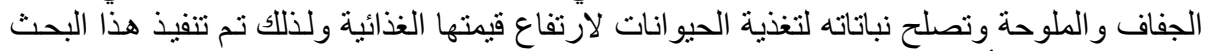

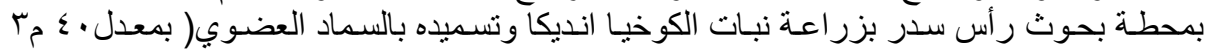

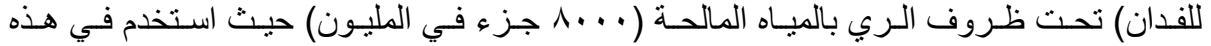

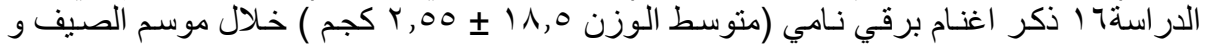

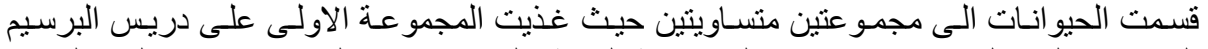

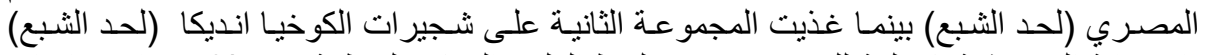

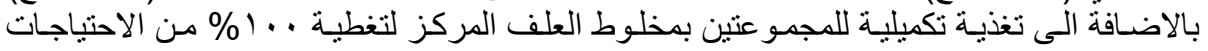

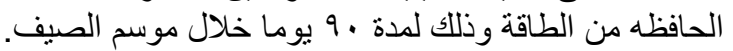

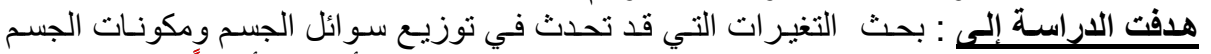

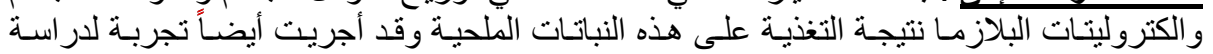

$$
\begin{aligned}
& \text { ميزان الماء Water balance study } \\
& \text { التجرية الأولى : التئي }
\end{aligned}
$$

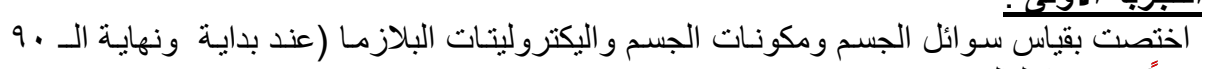

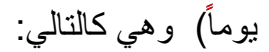

$$
\begin{aligned}
& \text { * سوائل الجسم الكلية TBW لكل حيوان باستخدام طريقة حيز الأنتيبيرين . }
\end{aligned}
$$

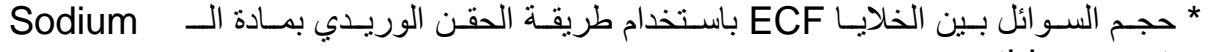

$$
\begin{aligned}
& \text {. thiocyanate } \\
& \text { * حجم بلازما الدم باستخدام الحقن الوريدي بصبغة الـ Evan's blue وبقياس الهيماتوكريت تم } \\
& \text { حساب حجم الدم باستخدام معادلة حسابية. }
\end{aligned}
$$

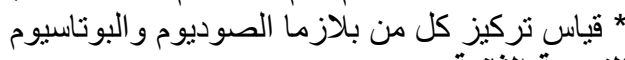

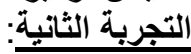

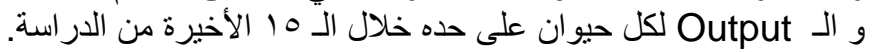

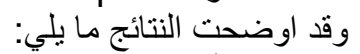

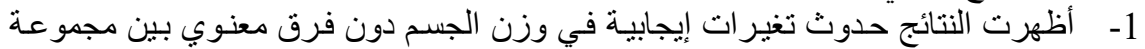

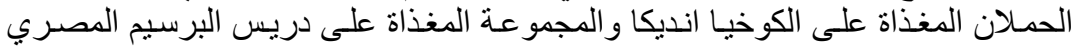

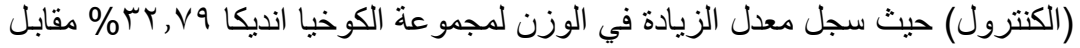

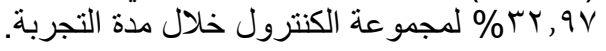


2- تساوت مجموعة الحملان المغذاه على الكوخيا انديكا مع تلك الكئ المغذاه على دريس الرسيم

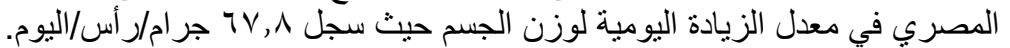

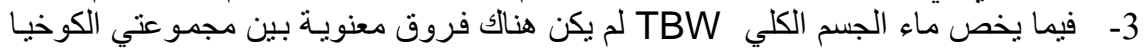

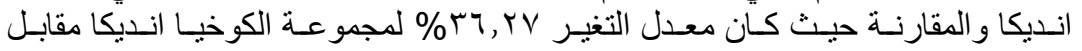

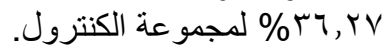

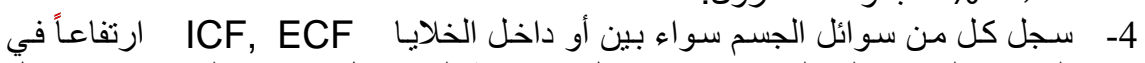

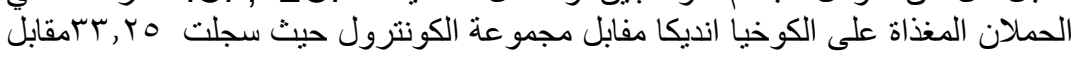

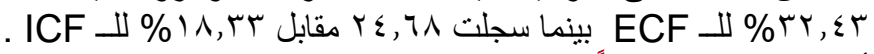

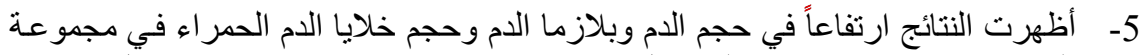

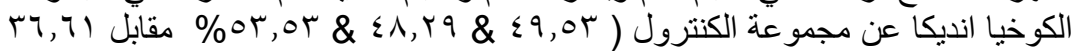
.

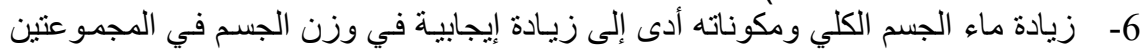

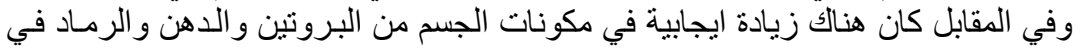
المجمو عتين.

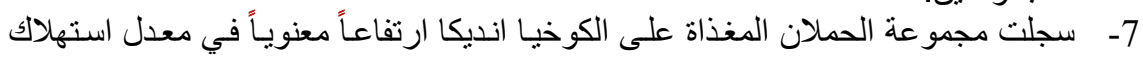

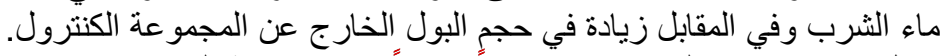

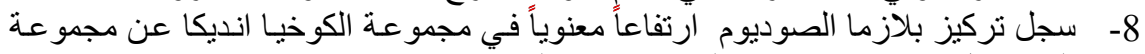

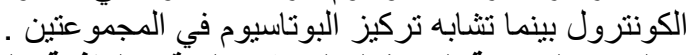

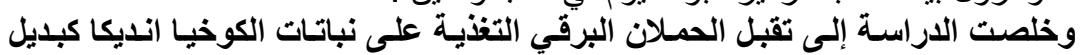

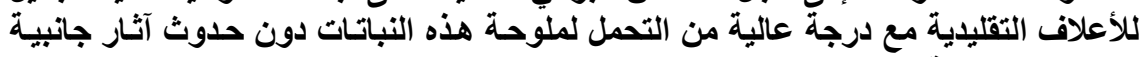
خلال مدة التجربة. 